\title{
ESSENTIAL OIL CONSTITUENTS OF NEEDLES, DRY NEEDLES, INFLORESCENCES AND RESINS OF PINUS CARIBAEA MORELET GROWING IN BANGLADESH
}

\author{
Jasim Uddin Chowdhury, Md. Nazrul Islam Bhuiyan* \\ and Nemal Chandra Nandi \\ BCSIR Laboratories, P.O. - Chittagong Cantonment, Chittagong-4220, Bangladesh
}

Key words: Pinus caribaea, Chemical composition, Essential oil, GC-MS

\begin{abstract}
Essential oils obtained by hydrodistillation from needles, dry needles, inflorescences and resin of Pinus caribaea Morelet were analyzed by GC-MS. Seven chemical constituents in oil of needles, 13 in dry needles, 4 in inflorescences and 6 in resin were identified. The major constituents found in the needle oil are limonene, caryophyllene and germacrene $D$ in the dry needle oil limonene, caryophyllene oxide and caryophyllene in the inflorescences oil caryophyllene oxide, limonene and crypton and in the resin oil bicyclo[3.1.1]hept-2-ene, 2,6,6trimethyl- (52.82\%), longifolen, crypton and $\beta$-pinene.
\end{abstract}

Pinus caribaea Morelet, a gymnosperm of the family Pinaceae, is a resinous woody tree with evergreen needlelike, leaves (Lee and Lee 1991). It occurs in a number of varieties. $P$. caribaea is native to Central America and the Caribbean. The volatile oil obtained by steam distillation from Pinus species is known as turpentine and the nonvolatile residue is the resin. In most cases alpha-pinene is the major product of the resin and it is one of the most important intermediates in the manufacture of synthetic aroma compounds and flavour ingredients. In this paper the authors describe the chemical composition of the essential oil from needles, dry needles, inflorescences and resin of $P$. caribaea collected from plants grown in the campus of BCSIR Laboratories, Chittagong, during July 2007 by hydrodistillation method for four hrs. The plant was identified by matching with voucher specimen preserved in the herbarium of BCSIR Laboratories. The isolated oils were dried over anhydrous sodium sulphate. A comparison has been made with oils produced plants by other $P$. caribaea grown in different geographical regions in the world.

The needles, dry needles, inflorescences and resin oil of $P$. caribaea were analyzed by electron impact ionization method on GC-17a gas chromatograph (Shimadzu) coupled to a QP 5050A Mass Spectrophotometer (Shimadzu). A fused capillary column (30 $\mathrm{m} \times$ $2.5 \mathrm{~mm}$ ) coated with DB-5 ms (J\&W) was used. Direct injection of $2 \mu \mathrm{l}$ samples with He as a carrier gas (at pressure of $100 \mathrm{Kpa}$ ) and oven temperature held isothermal at $50^{\circ} \mathrm{C}$ for $4 \mathrm{~min}$. and then programmed to increase at $10^{\circ} \mathrm{C} / \mathrm{min}$ to $150^{\circ} \mathrm{C}$ with keep time of 5 min which was further programmed to increase at $10^{\circ} \mathrm{C} / \mathrm{min}$ to $250^{\circ} \mathrm{C}$ with a keep time of 5 min. Acquisition parameters: full scan; scan range $40-350^{\circ} \mathrm{C}$, ionization voltage $70 \mathrm{ev}$. The essential oil composition was identified by comparing the mass spectra from NIST Library (NIST 147 \& NIST 27).

The fresh needles, dry needles, inflorescences and resin of $P$. caribaea contain 1.0, $0.15,0.16$ and $0.40 \%$ oil, respectively. The oils were colourless, having pleasant smell. Seven constituents in fresh needles, 13 in dry needles, 4 in inflorescences and 6 in resin oils chemicals were identified as major compounds, respectively and the amounts present in these four sources have been given (Table 1). Common constituent of oil from needles is $\alpha$-pinene both here and elsewhere in the world (Coppen et al. 1988, 1999, Dagne et al. 1999, Luis and Aragua 2000). On the basis of the present findings it may be 
concluded that $P$. caribaea growing in Bangladesh, may be utilized as a source for isolation of natural limonene, caryophyllene oxide and bicyclo[3.1.1]hept-2-ene, 2,6,6trimethyl.

${ }^{*}$ Corresponding author: <Nazrul119@yahoo.com>.

Table 1. Major constituents of essential oils from $P$. caribaea Morelet.

\begin{tabular}{|c|c|c|c|c|c|}
\hline \multirow{2}{*}{$\begin{array}{l}\text { Sl. } \\
\text { No }\end{array}$} & \multirow[b]{2}{*}{ Chemical constituents } & \multicolumn{4}{|c|}{ Sources } \\
\hline & & $\begin{array}{c}\text { Fresh } \\
\text { Needles }\end{array}$ & $\begin{array}{c}\text { Dry } \\
\text { Needles }\end{array}$ & $\begin{array}{l}\text { Inflore- } \\
\text { scences }\end{array}$ & $\begin{array}{c}\text { Resin } \\
\mathrm{s}\end{array}$ \\
\hline 1. & Limonene & 48.84 & 31.58 & 32.14 & - \\
\hline 2. & Caryophyllene & 23.82 & 14.45 & - & - \\
\hline 3. & Germacrene D & 8.40 & 2.59 & - & - \\
\hline 4. & $\alpha$-Caryophyllene & 6.51 & 4.76 & - & - \\
\hline 5. & $\alpha$-Pinene & 4.98 & 6.61 & - & - \\
\hline 6. & $\beta$-Myrcene & 3.78 & & & \\
\hline 7. & Caryophyllene oxide & 3.66 & 21.79 & 37.82 & - \\
\hline 8. & Benzene, 1-methyl-4-(1-methylethyl)- & - & 2.23 & - & - \\
\hline 9. & Bicyclo[3.1.1] hept-2-ene, 2,6,6-trimethyl- & - & - & - & 52.82 \\
\hline 10. & cis-Verbenol & - & - & - & 6.30 \\
\hline 11. & Crypton & - & - & 16.08 & 9.00 \\
\hline $12 .$. & Geraniol butyrate & - & 2.66 & - & - \\
\hline 13. & Linalyl acetate & - & 2.70 & - & - \\
\hline 14. & Longifolene & - & 3.27 & - & 18.66 \\
\hline 15. & Methyl chavicol & - & - & - & 5.08 \\
\hline 16. & $\beta$-Pinene & - & - & - & 8.13 \\
\hline 17. & $\begin{array}{l}\text { 1H-Cycloprop[e]azulen-4-ol, decahydro- } \\
\text { 1,1,4,7-tetramethyl- }\end{array}$ & - & 3.06 & - & - \\
\hline 18. & 2-Pentadecanone, 6,10,14-trimethyl- & - & 2.69 & - & - \\
\hline 19. & $\begin{array}{l}\text { 12-Oxabicyclo[9.1.0]dodeca-3,7-diene, } \\
\text { 1,5,5,8-tetramethyl- }\end{array}$ & - & 4.61 & - & - \\
\hline 20. & $\begin{array}{l}\text { 2-Cyclohexen-1-one, 2-methyl-5-(1- } \\
\text { methylethenyl)- }\end{array}$ & - & - & 13.96 & - \\
\hline
\end{tabular}

${ }^{*}$ Chemical constituents shown as \%.

\section{References}

Coppen, J.J.W., C. Gay, D.J. James, J.M. Robinson and I.J. Mullin. 1993. Xylem resin composition and chemotaxonomy of three varieties of Pinus caribaea. Phytochem. 33: 1103-1111.

Coppen, J.J.W., J.M. Ronbinson and I.J. Mullin. 1988. Composition of xylem resin from five Mexican and Central American Pinus species growing in Zimbabwe. Phytochem. 27: 17311734.

Dagne, E., T. Bekele, D. Bisrat, M. Alemayehu, T. Worku and J.P. Elokaokich. 1999. Essential oils of resins from three Pinus species growing in Ethiopia and Uganda. Ethiop. J. Sci. 22: 253257.

Lee, Y.S. and Lee, S.T. 1991. Modern Systematic Botany. U. Song Publishing, Seoul, p. 2. 
Luis Felipe Barnola and Aragua Cedeño. 2000. Inter-population differences in the essential oils of Pinus caribaea needles. Biochem. System. and Ecol. 28(10): 923-931.

(Manuscript received on 6 February, 2008; revised on 9 April, 2008) 